\title{
AS INCOMPATIBILIDADES DE APLICAÇÃO DO NEGÓCIO JURÍDICO PROCESSUAL NO DIREITO ELEITORAL
}

\author{
The incompatibilities of the application of procedural legal business in the electoral law
}

Luiza Cesar Portella

\author{
Luiz Magno Pinto Bastos Junior
}

Resumo: O presente artigo dedica-se à análise das incompatibilidades de aplicação do negócio jurídico processual, positivado no Novo Código de Processo Civil, no Direito Eleitoral. Ao longo do texto, constroem-se os pilares que afastam a implementação do inovador instituto processual na seara eleitoral. Para tanto, faz-se uma análise dos artigos 190 e 191 do Código de Processo Civil de 2015, à luz da evolução comparada ao Código de Processo Civil de 1973, apresentando o aprimoramento, as vantagens, e concluindo-se que, ao fim, o instituto é reflexo do Estado Democrático de Direito. Paralelamente, apresentam-se as balizas do Direito Eleitoral e as peculiaridades do seu processo, ressaltando as diferenças de regras procedimentais em face do Código de Processo Civil e, também, em face das previsões próprias da legislação eleitoral Diante do quadro retratado, inquieta-se a pesquisa em desvendar a compatibilidade, ou não, entre o inovador instituto do negócio processual e as peculiaridades inerentes ao processo eleitoral.

Palavras-chave: Processo civil. Negócio jurídico processual. Novo código de processo civil. Direito eleitoral. Processo eleitoral. Incompatibilidade.

\begin{abstract}
This article means to analyze the incompatibilities of applying the procedural business in Electoral Law. Throughout the text the pillars that prevent the enforcement of the procedural institute in the election field are developed. Therefore, an analysis is made of Articles 190 and 191 of the Code of Civil Procedure of 2015, at sight of comparison to the Code of Civil Procedure of 1973, presenting the improvement, the advantages and, concluding that in the end, the institute is reflecting the Democratic State of Law. Parallel to this, it presents the electoral law and the peculiarities of its process, highlighting the differences in procedural rules in the face of the Civil Procedure Code and also in view of the specific provisions of electoral legislation. The research in unveiling the compatibility, or not, between the innovative institute of the procedural business and the peculiarities inherent in the electoral process.
\end{abstract}

Keywords: Civil Procedure. Procedural business. New Code of Civil Procedure. Electoral Law. Electoral Procedure. Incompatibility.

Artigo recebido em 12 jul. 2018 e aprovado em 19 dez. 2018. 


\section{Introdução}

Com a entrada em vigor do dito Novo Código de Processo Civil, em 18 de março de 2016², muito se discutiu acerca da sua abrangência, sua compreensão, sua aplicabilidade, sua efetividade. Apesar de muitos dos novos institutos já estarem suficientemente aclarados no direito processual civil em geral, ainda é elevada a controvérsia sobre a aplicabilidade de diversos de seus institutos em outras esferas do direito, sobretudo, em relação ao direito eleitoral.

Anteriormente à entrada em vigência do novo diploma processual, a influência do Código de Processo Civil no Processo Eleitoral se dava exclusivamente de forma supletiva, ou seja, a sua importância era reservada à complementação quando inexistia norma, sendo ela necessária para o deslinde do caso. Atualmente, o diploma processual assume postura mais ativa, podendo ser aplicado em caráter tanto supletivo quanto subsidiário, o que, num primeiro momento, gerou dúvidas sobre a abrangência do instituto do negócio jurídico processual.

Este artigo defende, sem a pretensão de esgotar a temática, a incompatibilidade existente entre o inovador instituto do negócio jurídico processual e a sistemática peculiar do Processo Eleitoral.

Para tanto, as temáticas serão encadeadas nos seguintes termos: inicialmente, será feito um breve panorama do instituto denominado negócio jurídico processual, identificando suas origens e a sua natureza; na sequência, buscar-se-á apresentar uma visão global do direito eleitoral, principalmente no que tange às suas características materiais, com viés constitucional bastante evidente, e às peculiaridades processuais. Por fim, intenta-se conectar os fundamentos e indicar os motivos pelos quais são incompatíveis entre si, de modo a confirmar a determinação do Tribunal Superior Eleitoral de que o negócio jurídico processual - previsto no artigo 190 do Código de Processo Civil - não pode ser aplicado no processo eleitoral.

\footnotetext{
${ }^{1}$ A data foi fixada pelo Supremo Tribunal de Justiça a partir de decisão unânime do Pleno da Corte, que editou o Enunciado administrativo nำ 1, o qual foi assim redigido: “O Plenário do STJ, em sessão administrativa em que se interpretou o art. 1.045 do novo Código de Processo Civil, decidiu, por unanimidade, que o Código de Processo Civil aprovado pela Lei no 13.105/2015, entrará em vigor no dia 18 de março de 2016.”
} 


\section{Negócio jurídico processual: surgimento, natureza e características}

O Código de Processo Civil de 2016 trouxe ao sistema processual brasileiro uma série de inovações até então inimagináveis aos mais formalistas. Uma delas foi o instituto denominado pela doutrina de negócio jurídico processual. Ele está previsto nos artigos 190 e 191, insertos no Livro IV, Título I, Capítulo I, Seção I do novo diploma, sendo assim redigidos:

Art. 190. Versando o processo sobre direitos que admitam autocomposição, é lícito às partes plenamente capazes estipular mudanças no procedimento para ajustá-lo às especificidades da causa e convencionar sobre os seus ônus, poderes, faculdades e deveres processuais, antes ou durante o processo.

Parágrafo único. De ofício ou a requerimento, o juiz controlará a validade das convenções previstas neste artigo, recusando-lhes aplicação somente nos casos de nulidade ou de inserção abusiva em contrato de adesão ou em que alguma parte se encontre em manifesta situação de vulnerabilidade.

Art. 191. De comum acordo, o juiz e as partes podem fixar calendário para a prática dos atos processuais, quando for o caso.

$\int 1^{\circ} \mathrm{O}$ calendário vincula as partes e o juiz, e os prazos nele previstos somente serão modificados em casos excepcionais, devidamente justificados.

$\int 2^{2}$ Dispensa-se a intimação das partes para a prática de ato processual ou a realização de audiência cujas datas tiverem sido designadas no calendário.

Nota-se que tais dispositivos ampliaram, em muito, a autonomia e o poder das partes no processo, autorizando-as a alterar procedimentos e até prerrogativas, como o duplo grau de jurisdição.

A atribuição desse poder de disposição delegado às partes para, de certo modo, gerirem o próprio processo, deriva da nossa origem democrática, tendo uma vez que ele concretiza os direitos dos cidadãos típicos do Estado Democrático contemporâneo (GRECO, 2007). No mesmo sentido, Santos (2015) defende que a incapacidade de o cidadão interferir no processo que em ultima ratio definirá aspectos imperativos de sua esfera jurídica, fere as premissas do Estado Democrático de Direito. 
O que até aqui foi apresentado autoriza concluir que o negócio jurídico processual, do modo como inserido no novo diploma processual, concedeu autonomia aos cidadãos, excluindo do processo a ideia de Estado controlador, autoritário e inflexível sem, contudo, caracterizar a privatização e a anarquização do processo civil brasileiro ${ }^{2}$.

Acrescenta-se a esse entendimento a ideia de Marina França Santos (2015), a qual defende que a ideia de rigidez processual não mais se coaduna com o direito no século XXI. Isso porque a manutenção das regras processuais estanques em confronto com o postulado democrático que inclui a participação das partes fere o preceito anterior de que a segurança jurídica só seria mantida com a existência de regras heterônomas em todo se afasta do que se espera hoje do direito.

Barbosa Moreira (1983) há muito já indicava situações em que as partes poderiam convencionar sobre matéria processual. Ele apontava, desde 1983, a ausência de estudos monográficos acerca do tema. Com a disposição expressa no novo diploma civil, tal realidade foi alterada de modo que o instituto ganhou foco e passou a ser analisada com clareza ${ }^{3} 5$.

No código de 1973, já podíamos vislumbrar espécies de acordos individuais que tinham a prerrogativa de alterar o procedimento positivado:

\footnotetext{
${ }^{2}$ Nesse sentido, reforçam a ideia os ensinamentos de Gajardoni (2011), segundo o qual bastaria que as normas fossem conhecidas pelas partes previamente à sua implementação para que sejam ilegais e respeitem a segurança jurídica, não importando a fonte de onde provenham. Disso se extrai que não é apenas a formalização excessiva e o Estado rígido e formalista que garantem a segurança jurídica, mas sim a previsibilidade do procedimento.

${ }^{3}$ Ada Pellegrini Grinover, Cândido Rangel Dinamarco e Antonio Carlos de Araújo Cintra (2004), no momento em que escreveram o livro, defenderam que a doutrina negava a existência de negócios processuais, de modo que hoje, com a sua positivação, faz-se essencial a mudança de posicionamento doutrinário a fim de se adequar à nova realidade.

${ }^{4}$ No mesmo sentido, José de Albuquerque Rocha defendia a inexistência de negócios processuais. Segundo o autor, as partes não poderiam influenciar o desenvolvimento do processo, de modo que seu único papel é praticar o ato, e não alterar os efeitos dele, decorrentes previstos em lei (BRAGA, 2007).

${ }^{5}$ Alexandre Freitas Câmara também entendia que os atos das partes se resumiam a desencadear os efeitos previstos em lei (BRAGA, 2007).
} 
a eleição contratual do foro ${ }^{6}$, a convenção sobre suspensão do processo $^{7}$, sobre distribuição do ônus da prova ${ }^{8}$, sobre adiamento de audiência ${ }^{9}$, dentre tantos outros (MOREIRA, 1983). Ainda analisando o diploma anterior, Paula Sarno Braga (2007) já admitia a possibilidade de celebração de convenções processuais não previstas em lei, desde que, de mesmo modo, não contrariassem a nenhuma delas.

Naquele momento, não havia um consenso doutrinário acerca da nomenclatura a se emprestar ao instituto. Barbosa Moreira (1983), então, remete ao direito alemão, no qual o denominavam de contrato processual. Expõe que havia quem adotasse a expressão alemã, outros que defendiam a terminologia "avenças" ou ainda "acordos processuais", preferindo o autor a denominação "convenções processuais".

Bem se vê que o tema desse estudo em muito evoluiu, até ser formalizado em um vernáculo abrangente e específico no Código Processual Civil de 2016, sobre o qual há mínimo consenso doutrinário e jurisprudencial, nem que seja no que tange sua denominação ${ }^{10}$.

${ }^{6}$ Art. 111. A competência em razão da matéria e da hierarquia é inderrogável por convenção das partes; mas estas podem modificar a competência em razão do valor e do território, elegendo foro onde serão propostas as ações oriundas de direitos e obrigações.

$\int 1^{\circ} \mathrm{O}$ acordo, porém, só produz efeito quando constar de contrato escrito e aludir expressamente a determinado negócio jurídico.

$\int 2^{\circ} \mathrm{O}$ foro contratual obriga os herdeiros e sucessores das partes.

${ }^{7}$ Art. 265. Suspende-se o processo:

$[\ldots]$

II - pela convenção das partes;

$[\ldots]$

${ }^{8}$ Art. 333. O ônus da prova incumbe:

I - ao autor, quanto ao fato constitutivo do seu direito;

II - ao réu, quanto à existência de fato impeditivo, modificativo ou extintivo do direito do autor.

Parágrafo único. É nula a convenção que distribui de maneira diversa o ônus da prova quando:

I - recair sobre direito indisponível da parte;

II - tornar excessivamente difícil a uma parte o exercício do direito.

${ }^{9}$ Art. 453. A audiência poderá ser adiada:

I - por convenção das partes, caso em que só será admissível uma vez;

${ }^{10}$ Leonardo Greco (2007), ao explicar a evolução doutrinária acerca da compreensão da interferência das partes no processo, cita Carnelutti. Este, já em 1944, falava em negócio jurídico processual que acabou sendo, hoje, a terminologia utilizada para referenciar o instituto previsto nos artigos 190 e 191 do Código de Processo Civil.

Resenha Eleitoral (Florianópolis), v. 22, n. 1-2, p. 51-76, 2018 
O novo sistema processual acabou afastando-se do que era preconizado no Código Processual Civil de 1973. Neste, a proximidade com o sistema da legalidade das formas procedimentais era bastante evidente, de modo que prevalecia a máxima de que tanto a previsão de certo ato, quanto a sua consequência, eram previamente definidas por lei, sem possibilidade de mudança.

Por outro lado, o novo diploma, ao institucionalizar o cabimento do negócio jurídico processual (nas condições abaixo verificadas), aproximou-se do sistema da liberdade de formas procedimentais, segundo o qual as partes teriam total liberdade para definir todos os vieses procedimentais do processo (GAJARDONI, 2011). Evidente que esse sistema não foi totalmente adotado, acreditando-se que sequer seria bem recepcionado em nossa realidade jurídica, todavia, foi um passo para conferir maior dinamicidade ao processo e, por conseguinte, democratizá-lo.

Assim, é possível, a partir dos ensinamentos de Barbosa Moreira (1983), perceber a condição primária do negócio jurídico: para que o negócio jurídico processual seja válido, faz-se necessário o acordo mútuo e coincidente de vontades. Apenas assim as mudanças se tornam efetivamente aplicáveis e positivas.

Leonardo Greco (2007), reforçando o apresentado por Barbosa Moreira, ensina que as convenções das partes, preconizadoras do negócio jurídico processual, são atos bilaterais, de comum acordo, que podem ser travadas antes de formada a lide ou no curso do processo, a fim de definir questões específicas referentes a ele. Esse também é o entendimento de Paula Sarno Braga (2007, p. 20) segundo a qual "[...] o fato ou complexo de fatos que, juridicizado pela incidência de norma processual, é apto a produzir efeitos dentro do processo".

Comparando as previsões esparsas do código de $1973^{11}$ e o ditame expresso do de 2016, nota-se que a condição primária sempre existiu e já era condicionante para a implementação das modificações procedimentais, de modo que, hoje, especialmente em virtude da sua amplitude, deve-se priorizar a concordância das partes, tendo em vista a igualdade material e processual entre elas.

Braga (2007) complementa trazendo à tona a ideia de Francesco Carnelutti segundo o qual a natureza do ato como processual ou não inde-

${ }^{11}$ Vide notas de rodapé $6,7,8$ e 9. 
pende de ter sido realizado dentro ou fora do processo, mas decorre da sua importância para a causa. Não satisfeita, analisando a natureza jurídica do negócio processual, acrescenta que, nos negócios processuais discricionários, necessariamente as partes definem o efeito jurídico do que for acordado, ou seja, elas direcionam a transação privada para um fim específico e preconcebido.

O parágrafo único do artigo 190 do Código, por sua vez, institui o papel do magistrado nas convenções, resumindo-o a um mero fiscal, não lhe atribuindo postura ativa, sequer chancelatória. Ou seja, o que o recente legislador prescreveu foi que o juiz apenas poderá negar o acordo quando ele se mostrar nulo ou abusivo.

O artigo 191, por seu turno, vai ainda mais além, recepcionando o julgador ao acordo e autorizando que, em conjunto, ele e as partes, fixem um calendário pormenorizado para a prática dos atos processuais ${ }^{12}$.

Essa autonomia do juiz e, principalmente, das partes, não se via no diploma de 1973, de modo que as convenções processuais abordadas com maestria por Barbosa Moreira evoluíram até chegar ao patamar atual. Nota-se, pois, que as partes passaram a desempenhar papel mais ativo no processo, e menos de meros espectadores.

Barbosa Moreira (1983) estabeleceu alguns parâmetros para que as convenções processuais fossem válidas, parâmetros esses que ainda podemos adotar atualmente. São eles: para a sua realização extrajudicial, basta que a parte tenha capacidade civil, sem necessitar da capacidade postulatória; de mesmo modo que, se realizada judicialmente, basta ter capacidade postulatória e não a capacidade civil, ou seja, antes da formação da lide, as partes não precisam de advogado para acordarem, e, após iniciado o processo, o espólio ou o condomínio, por exemplo, que não possuem personalidade jurídica, podem, perfeitamente, travar as convenções.

Quanto à forma, afirma que, do mesmo modo que ocorre no direito material, não havendo restrição legal, a convenção pode apresentar forma livre. Acrescenta, ainda, como requisitos, a licitude do acordo e a possibilidade do objeto. Impõe restrição, todavia, no que toca a adoção de condição ou de termo.

\footnotetext{
${ }^{12}$ Moreira (1983) já ressaltava que, mesmo as convenções que precisam da chancela do magistrado, mantém a natureza de convenção processual - hoje conhecida por negócio jurídico processual - de modo que a sua caracterização derivava do ato uno emitido pelas partes em declaração de vontade congruente.
} 
A liberalidade e a liberdade das partes, contudo, não é completa. $\mathrm{O}$ artigo 190 do Código de Processo Civil restringe os negócios jurídicos processuais aos processos que versem sobre direitos que admitam autocomposição. Nada obstante, significa dizer "[...] que o instituto não é avesso à tutela de direitos fundamentais ${ }^{13}$, mas sim seu fomentador." (BUCHMANN, 2017, p. 178). Sendo isso permitido, o legislador, ao idealizar o instituto "[...] criou mecanismos a permitir o controle da validade da pactuação pelo magistrado." 14 (BUCHMANN, 2017, p. 179).

Nesse sentido, é essencial observar limites objetivos que delimitam a extensão do mecanismo: (i) disponibilidade do direito discutido ${ }^{15}$, (ii) equilíbrio entre as partes e igualdade concreta de defesa e de meios de ação, (iii) respeito aos princípios e garantias fundamentais do processo (GRECO, 2007). Lembra-se ainda que, por ser um negócio jurídico, precisa observar os requisitos de validade adjacentes a todos os demais, como previsto no Título I, do Livro III do Código Civil.

Tais parâmetros, defendidos anteriormente em análise ao Código Processual Civil de 1973, foram reproduzidos no parágrafo único do artigo $190^{16}$, o qual delegou ao juiz a tarefa de garantir que os limites sejam respei-

${ }^{13}$ No mesmo sentido, é possível colher entendimento de Marina França Santos (2015, p. 99), a qual defende que: "O substrato constitucional do processo ora nenhuma exclui a liberdade das partes de conformação do procedimento, cingindo-se a limitar qualquer forma a ser estabelecida aos postulados mínimos estabelecidos pela Constituição de 1988 como o contraditório e a ampla defesa, a fundamentação das decisões, a duração razoável do processo, a publicidade e a imparcialidade dos julgamentos e a licitude das provas."

${ }^{14}$ Tal entendimento é corroborado por Leonardo Greco (2007, p. 11), o qual afirma que: "Isso não significa que os titulares de direitos indisponíveis não possam praticar atos de disposição, tanto no sentido de atos prejudiciais quanto de atos decisórios, mas apenas que não podem praticar os que, direta ou indiretamente, possam prejudicar ou dificultar a tutela desses direitos."

${ }^{15}$ Faz-se a ressalva de que, atualmente, essa compreensão foi de certo modo relativizada, de modo que mesmo quando tocam direitos fundamentais, é possível que as partes, cientes do que está em jogo, possam transigir. Nesse sentido: "Da redação empregada ao artigo 190, exsurge um enquadramento aos negócios jurídicos processuais que se sobrepõe à seara dos litígios envolvendo direitos meramente patrimoniais, até mesmo porque, caso fosse essa a intenção do legislador, ele teria disciplinado a matéria nos mesmos termos em que o fez com a arbitragem." (BUCHMANN, 2017, p. 179)

${ }^{16}$ Parágrafo único. De ofício ou a requerimento, o juiz controlará a validade das convenções previstas neste artigo, recusando-lhes aplicação somente nos casos de nulidade ou de inserção abusiva em contrato de adesão ou em que alguma parte se encontre em manifesta situação de vulnerabilidade. 
tados, limitando aos casos de descumprimento a possibilidade de recusa ao negócio jurídico processual. Ou seja, não existe a subordinação a condições ou a termos, sendo a análise judicial mero ato formal para que o negócio continue a emanar seus efeitos, desde que não seja eivado de qualquer nulidade (GRECO, 2007).

Tem-se, assim, que a ampliação da possibilidade de disposição das partes sobre o procedimento no processo mostra-se forma de adequar o processo nos âmbitos subjetivo, objetivo e teleológico. Reforça ainda a ideia de que ao adequá-lo às necessidades e às específicas condições das partes e da demanda, a resolução do conflito tenderá a mostrar-se mais eficiente e mais eficaz (SANTOS, 2015).

A autora ainda complementa ensinando que a origem constitucional do processo não vai de encontro com a possibilidade de as partes transigirem sobre o procedimento, pelo contrário, limitando-as à observação dos princípios basilares, como o contraditório e a ampla defesa, a fundamentação das decisões, a duração razoável do processo, a publicidade e a imparcialidade dos julgamentos, além da licitude das provas.

Conclui que o negócio jurídico processual concretiza o princípio da adequação do procedimento que, por sua vez, deriva dos princípios do acesso à justiça e do devido processo legal de modo a legitimar o processo adequado à realidade de direito material.

Dessa forma, o negócio jurídico processual se transmuda em uma cláusula aberta (SANTOS, 2015) de liberalidade das partes para ajustarem o procedimento da forma como melhor lhes convêm. Essa conclusão é possível uma vez que o Código não restringiu as possibilidades de convenção como fazia seu antecessor, mas autoriza qualquer modificação, desde que dentro dos limites já apresentados.

Assim, pode-se considerar que o instituto do negócio jurídico processual representa autorização "[...] legal de aprofundamento da participação das partes no processo, que passam a não apenas participar dos atos com vistas a influenciar a cognição judicial, como também a poder elaborar os próprios atos de que participam.” (SANTOS, 2015, p. 96).

Fundamental, portanto, reconhecer o potencial inovador do instituto, uma vez que ele rompe com o paradigma até então vigente na seara do processo, permitindo aos operadores jurídicos a eleição de mecanismos de gerenciamento processual até então inimagináveis, os quais fatalmente 
propiciarão maior celeridade ${ }^{17}$ ao procedimento. Celeridade, por sinal, que é tida enquanto uma das mais marcantes características do processo eleitoral, ao qual se dedica o capítulo seguinte.

\section{O universo eleitoral: características materiais e peculiaridades processuais}

O Direito Eleitoral é ramo do direito que, apesar de extremamente importante e fundamental para o Estado Democrático, fora negligenciado no passado, quando não existiam muitos pesquisadores e doutrinadores do estudo eleitoral democrático ${ }^{18}{ }^{19}$. No entanto, felizmente, esse cenário vem mudando, seja pelo interesse social, acadêmico, doutrinário, político, seja pelo interesse prático.

Inicialmente, antes de se adentrar na apresentação da matéria, é importante esclarecer o cenário no qual o direito eleitoral brasileiro está inserido.

Quando se fala em legislação eleitoral, é preciso ter em mente que não se pode restringir o estudo unicamente ao Código Eleitoral. Não. Existem hoje diversas leis - e resoluções do Tribunal Superior Eleitoral ${ }^{20}$ que regulamentam, cada uma na sua esfera, uma parte do Direito Eleitoral. Tem-se, por exemplo, além do Código Eleitoral (Lei no 4.737/1965), a chamada Lei das Eleições (Lei no 9.504/1997), a Lei dos Partidos Políticos (Lei no 9.096/1995), a Lei das Inelegibilidades (Lei Complementar no 64/1990), a Lei da Ficha Limpa (Lei Complementar no. 135/2010), para citar apenas as principais.

Com tanta regulamentação, contudo, não se pode esquecer o caráter constitucional do Direito Eleitoral, sendo a Constituição da República

\footnotetext{
${ }^{17}$ Essa celeridade, por exemplo, poderá se observar nos casos de dispensas recíprocas de intimação, ou de dispensa ao segundo grau de jurisdição, ou ainda pelo acordo de instrução probatória reduzida, excluindo-se a realização de audiência para oitiva de testemunhas, ou a realização de perícia.

${ }^{18}$ Viana Pereira, citado por José Jairo Gomes (2016, p. 62), defende que Direito Eleitoral "parece ter se mantido na penumbra, em um território fosco em que predomina uma espécie de desprezo teórico, e mesmo legislativo, relativamente a vários de seus institutos".

${ }^{19}$ No mesmo sentido, Jairo Gomes (2016, p. 62) conclui que “[...] o Direito Eleitoral, como ciência, ainda se encontra empenhado no desenvolvimento de seu método e conteúdo.”

${ }^{20}$ Ao referir-se ao Tribunal máximo eleitoral neste artigo, poder-se-á utilizar a sigla pela qual é comumente conhecido, 'TSE'.
} 
a sua fonte primária, tendo instituído importante regramento já quando da sua edição em 1988, a qual fixou sua base, principalmente nos artigos 17, 45 e 46. Dessa forma, toda as demais fontes do Direito Eleitoral, sejam elas legislativas, jurisprudenciais, ou normativas oriundas dos tribunais, devem respeitar e fomentar a garantia constitucional à soberania popular, à república federativa, à democracia representativa, ao sufrágio, às condições de elegibilidade, entre tantos outros valores com os quais a Constituição de 1988 nos presenteou.

Neste ponto, é de extrema relevância destacar que o Código Eleitoral foi instituído em 15 de julho de 1965, durante a ditadura militar que assolou o país durante 21 anos. Ou seja, insta dizer que - em tese - a norma máxima regulamentadora do direito eleitoral brasileiro não tem origem democrática, mas, sim, ditatorial.

Tal característica, mas não só ${ }^{21}$, fez com que o legislador não apenas editasse novas normas com finalidades específicas (como as anteriormente citadas), como também realizasse minirreformas no Código ${ }^{22}$. Contudo, essa formatação cria um sistema díspar, antiquado e fragmentado que, segundo o Ministro Gilmar Mendes, presidente do Tribunal Superior Eleitoral, em reportagem editada pelo TSE (2017), não acompanhou o processo de redemocratização que originou a Constituição de 1988, tendo sido mantido o sistema político-eleitoral vigente desde 1932, evidenciando, pois, a necessidade de mudança sistematizada.

Por esse motivo que, mais uma vez, tenta-se aprovar um aperfeiçoamento efetivo no sistema eleitoral. O Ministro Gilmar Mendes, ao falar sobre a reforma que tramita na Câmara dos Deputados, posicionou-se no sentido de que é evidente a fragilidade do nosso sistema político-eleitoral, o qual se mostra extremamente viciado a quem quiser enxergar. Continua o Ministro, defendendo que, da forma como está projetado, o sistema é vulnerável a manipulações, devendo, urgentemente, ser discutido e alterado (TSE, 2017).

${ }^{21} \mathrm{O}$ procedimento eleitoral (alistamento, eleição, apuração, financiamento, prestação de contas), em muito evoluiu nessas últimas seis décadas, de modo que a legislação original não tinha aporte de acompanhar, sequer de recepcionar em seu texto, as mudanças necessárias para adequá-lo à realidade contemporânea.

22 As minirreformas foram efetuadas através das Leis nos 11.300/2006, 12.034/2009, 12.891/2013, 13.165/2015, sem contar as inúmeras alterações que a Lei no 4.961/1966 inseriu no Código Eleitoral.

Resenha Eleitoral (Florianópolis), v. 22, n. 1-2, p. 51-76, 2018 
Ultrapassada a exposição do cenário atual em que se encontra o Direito Eleitoral, passa-se à análise de suas características materiais e de suas peculiaridades processuais.

O Direito Eleitoral apresenta-se como ramo do Direito Público - no qual ao Estado é atribuído o papel de poder político soberano - que regulamenta, através de normas e de procedimentos, as normas constitucionais fundamentais, tais quais o direito de sufrágio, visando, ao fim, consolidar a soberania popular, dar legitimidade à representação, à ocupação de cargos políticos e ao exercício do poder estatal (GOMES, 2016), fundando-se, por fim, no regime democrático.

Lenza (2011) reforça o conceito ao definir o Direito Eleitoral como defensor do direito ao sufrágio, englobando a capacidade eleitoral ativa (direito de votar) e passiva (direito de ser votado), o direito à filiação partidária, e ao cuidado com as eleições (preparação, regulamentação, organização, apuração, fiscalização).

Em complemento, Rodrigues (2010) afirma que tanto as regras de direito material eleitoral quanto as de direito processual eleitoral devem visar à efetivação da democracia a partir da soberania popular, incluindo nesse dever aquelas que organizam a justiça eleitoral, o sufrágio popular e os partidos políticos.

O Direito Eleitoral, pois, busca proteger direitos e princípios essenciais à sociedade como "[...] a democracia, a legitimidade do acesso e do exercício do poder estatal, a representatividade do eleito, a sinceridade das eleições, a normalidade do pleito e a igualdade de oportunidades entre os concorrentes." (GOMES, 2016, p. 62).

Com isso em mente, interessante relembrar que o Direito Eleitoral possui ainda mais uma peculiaridade: quem produz as leis eleitorais (competência privativa do Congresso Nacional) é o seu próprio destinatário. Ou seja, é preciso cautela na validação e na aplicação legislativa visto que seria ingenuidade pensar que elas são escritas com completa isenção pessoal e em observância aos princípios constitucionais tão prezados ${ }^{23}$.

${ }^{23}$ Apresenta-se para reflexão, por exemplo, a regulamentação do fundo partidário. Com a proibição, em 2015, de financiamento dos partidos e das campanhas eleitorais (cada vez mais caras, diga-se de passagem), a captação de recursos ficou limitada às cotas oriundas do fundo partidário e às doações de pessoas físicas. Haja vista que o Brasil não tem qualquer tradição contributiva da população ao financiamento partidário e político, a grande maioria das contas será paga com dinheiro público. Assim, é de se imaginar o grande in- 
Origina-se, pois, precipuamente, da Constituição Federal, a qual fixa os seus princípios fundamentais além de outros conceitos e normas ${ }^{24}$, a partir dos quais as regras infraconstitucionais eleitorais são criadas.

Conforme já dito, possui diversas leis esparsas que, em conjunto com o Código Eleitoral, delimitam o seu conteúdo. Vale ressaltar, entretanto, que grande parte das regulamentações eleitorais são formuladas a partir de Resoluções do TSE. Este, portanto, atua como fonte normativa, não apenas regulando o que foi previsto em lei, mas inovando e suprindo lacunas legislativas (RODRIGUES, 2010).

As resoluções, por sua vez, são classificadas como ato-regra com força de lei e regulamentadas pelo artigo 105 da Lei das Eleições. Esse artigo define o dia 5 de março do ano em que ocorrerá a eleição como limite para a expedição de resolução que regerá aquele certame.

Pois bem, isso significa que a sete meses das eleições, o Tribunal Superior Eleitoral pode alterar toda a regulamentação para o pleito, desde que não contrarie ditame legal. Assim, é possível que a nova resolução acabe por prejudicar a organização dos partidos, seu planejamento financeiro, a programação dos programas televisionados, a orientação de prestação de contas. Ou seja, o poder atribuído ao TSE é imenso e, nem sempre, regular e perene, colocando em xeque a estabilidade processual eleitoral.

Isso deriva das quatro funções atribuídas à justiça eleitoral, quais sejam: administrativa, jurisdicional, normativa e consultiva (GOMES, 2016). A justiça eleitoral, como ramo autônomo do judiciário, surgiu em 1930 (LENZA, 2011; ROSAS, 1999) e foi regulamentada pelo Código Elei-

teresse que os parlamentares possuem na Reforma Eleitoral. Uma das ideias é criar o que foi chamado de Fundo de Financiamento da Democracia (FFD), o qual seria custeado por verbas públicas e responderia por 70\% das contas de campanha, relegando os 30\% restantes à pessoa física. $\mathrm{O}$ que mais assusta é a soma com a qual o FFD partiria: 2,1 bilhões de reais (VENAGLIA, 2017). Agora se instiga se, caso aprovada, essa medida efetivamente é de maior interesse da população, ou se servirá para resolver de forma fácil - e de alto custo para o erário - o impasse gerado. Por essa razão é que é preciso sempre atentar para essa peculiaridade, pois apesar de tantas outras leis terem os parlamentares como destinatários, nenhuma delas os atinge tão fortemente e em ponto tão crucial: a sua manutenção no poder. ${ }^{24}$ Dentro o fixado pela constituição, podemos identificar como chave para o direito eleitoral o sistema de governo (art. 1ํ), os direitos políticos (art. 14), a nacionalidade (art. 12), fundamental para definir os limites dos direitos políticos, os partidos políticos (art. 17), a competência legislativa em matéria eleitoral (art. 23, I), a organização da Justiça Eleitoral (art. 118 e seguintes). 
toral de 1932. Ela se apresenta como instrumento de garantia da lisura no processo eleitoral, assim como de preservação dos direitos e garantias fundamentais eleitorais (LENZA, 2011), como a liberdade de voto, a garantia de voto às mulheres, o incentivo de participação da mulher na política, o direito de votar e de ser votado.

Atualmente, a justiça eleitoral consiste em um desmembramento da justiça federal, sendo composta por juízes de carreira estaduais e federais, além de membros oriundos da classe dos advogados, exercendo, todos, mandatos de dois anos, prorrogáveis uma vez pelo mesmo período. Percebe-se, pois, que a justiça eleitoral não possui quadro próprio de julgadores, circunstância que gera dualidade entre aqueles que pesquisam o Direito Eleitoral ou trabalham com ele.

Acredita-se que essa pluralidade reforça seu caráter pluralístico democrático, na medida em que busca alcançar diferentes segmentos de representação nos âmbitos jurídicos, bem como alterná-los periodicamente no exercício da função evitando-se, assim, a perpetuação de ideias e ideais numa corte eleitoral e política. Por outro lado, reconhece-se que a mudança constante traz prejuízos ao jurisdicionado que, muitas vezes, acaba sendo pego de surpresa pela alteração da composição e, consequentemente, da jurisprudência, inclusive durante uma mesma eleição. Esse problema, no entanto, é facilmente superado pela observância dos precedentes ${ }^{25}$ e pela manutenção de mesma linha de posicionamento, pelo menos, no que se refere ao mesmo período temporal ou à mesma eleição.

O processo eleitoral, por sua vez, funda-se no controle das eleições e consiste na:

[...] complexa relação que se instaura entre Justiça Eleitoral, candidatos, partidos políticos, coligações, Ministério Público e cidadãos com vistas à concretização do sacrossanto direito de sufrágio e escolha, legítima, dos ocupantes dos cargos público-eletivos em disputa (GOMES, 2016, p. 369).

\footnotetext{
${ }^{25}$ Esse é outro ponto de destaque que possui vasto campo para estudo e ponderação no que tange, especificamente, aos preceitos estabelecidos pelo Código de Processo Civil de vinculação aos precedentes (art. 926), de resolução de demandas repetitivas (arts. 976 a 987), e de assunção de competência (art. 947).
} 
Marcelo Rodrigues (2010) ressalva que, apesar de o processo eleitoral ser fundamental para a manutenção da democracia, durante muito tempo foi negligenciado ${ }^{26}$. Um dos fatores que o autor menciona é o que chama de "balbúrdia legislativa". Destrincha-o em três fatores: (i) o Código Eleitoral ditatorial prévio à Constituição de 1988; (ii) falta de interesse do legislativo em desmitificar e sistematizar as técnicas processuais eleitorais, mantendo o sistema confuso para dificultar o acesso à justiça pela população; (iii) não há preocupação em estabelecer um sistema processual linear, resultando na criação de soluções pontuais e casuísticas para cada imbróglio que surja.

Gomes (2016) demonstrou que a doutrina convencionou como termo inicial do Processo Eleitoral o dia 20 de julho do ano eleitoral, visto que corresponde à data a partir da qual as convenções partidárias são autorizadas, encerrando-se com a diplomação dos candidatos eleitos. Ou seja, conclui-se que ela é composta por ciclos eleitorais que, muitas vezes, acabam perdurando no tempo e se confundem com o próximo ciclo.

Nesse cenário, tinha-se, até a edição do Código de Processo Civil de 2016, que este se aplicava subsidiariamente ao processo eleitoral. Contudo, com a sua entrada em vigor, o seu artigo $15^{27}$ passou a definir que a sua interferência será maior, podendo ser aplicado supletivamente.

Por outro lado, o Processo Eleitoral é protegido pela Constituição da República, visto que ele resguarda a legitimidade das eleições de modo a legitimar o exercício da democracia (GOMES, 2016).

O Processo Eleitoral possui ainda outra peculiaridade: ele não segue um procedimento único, padronizado para todas as ações, com mesmos prazos, e mesmos recursos cabíveis. Isso, por si só, dificulta a transposição das normas de Processo Civil para as normas de Processo Eleitoral.

Além disso, diversos desses procedimentos estão previstos em normativas distintas. Por exemplo, a Ação de Impugnação de Mandato Eletivo tem previsão constitucional, sendo regulada pelos parágrafos 10 e 11

${ }^{26}$ Entende-se que o processo eleitoral continua sendo negligenciado, ainda mais que o direito material eleitoral. A criação de um Código de Processo Eleitoral, incluindo normas de processo eleitoral civil e normas de processo eleitoral penal, representaria uma grande evolução para a autonomia processual eleitoral, de modo que sanaria as constantes dúvidas de aplicação ou dispensaria que fosse regulado pelo TSE através de uma norma não legislativa, como a que constitui objeto deste artigo.

${ }^{27}$ Art. 15 . $\mathrm{Na}$ ausência de normas que regulem processos eleitorais, trabalhistas ou administrativos, as disposições deste Código lhes serão aplicadas supletiva e subsidiariamente.

Resenha Eleitoral (Florianópolis), v. 22, n. 1-2, p. 51-76, 2018 
do artigo 14 da Constituição da República. A Ação de Investigação Judicial Eleitoral, por sua vez, ordena-se a partir do artigo 22 da Lei Complementar no 64/1990. A Ação de Perda de Mandato Eletivo é totalmente regulada pela Resolução n⿳ำ 22.610/2007.

Denota-se que as ações específicas podem ser reguladas por diversos tipos diferentes de normas, apresentando cada uma delas com um rito distinto, com regras peculiares, prazos, instrução e consequências diferentes.

O Código Eleitoral, por sua vez, fixa algumas regras peculiares ao processo eleitoral que não permitem a interferência do Código de Processo Civil, afastando por completo a supletividade. São algumas delas: (i) os recursos eleitorais, em regra, não terão efeito suspensivo ${ }^{28}$, diferente da regra do processo civil $^{29}$, que já autoriza o magistrado a deferi-lo tão logo receba o recurso; (ii) prazo de três dias corridos para a interposição de recursos, desde embargos de declaração, até recurso extraordinário ${ }^{30}$; (iii) os prazos

\footnotetext{
${ }^{28}$ Art. 257. Os recursos eleitorais não terão efeito suspensivo.

\1ำ A execução de qualquer acórdão será feita imediatamente, através de comunicação por ofício, telegrama, ou, em casos especiais, a critério do presidente do Tribunal, através de cópia do acórdão.
}

$\int 2^{\circ} \mathrm{O}$ recurso ordinário interposto contra decisão proferida por juiz eleitoral ou por Tribunal Regional Eleitoral que resulte em cassação de registro, afastamento do titular ou perda de mandato eletivo será recebido pelo Tribunal competente com efeito suspensivo.

$\int 3^{\circ} \mathrm{O}$ Tribunal dará preferência ao recurso sobre quaisquer outros processos, ressalvados os de habeas corpus e de mandado de segurança.

${ }^{29}$ Art. 995. Os recursos não impedem a eficácia da decisão, salvo disposição legal ou decisão judicial em sentido diverso.

Parágrafo único. A eficácia da decisão recorrida poderá ser suspensa por decisão do relator, se da imediata produção de seus efeitos houver risco de dano grave, de difícil ou impossível reparação, e ficar demonstrada a probabilidade de provimento do recurso.

Art. 1.012. A apelação terá efeito suspensivo.

$\int 1^{\circ}$ Além de outras hipóteses previstas em lei, começa a produzir efeitos imediatamente após a sua publicação a sentença que:

Art. 1.019. Recebido o agravo de instrumento no tribunal e distribuído imediatamente, se não for o caso de aplicação do art. 932, incisos III e IV, o relator, no prazo de 5 (cinco) dias: I - poderá atribuir efeito suspensivo ao recurso ou deferir, em antecipação de tutela, total ou parcialmente, a pretensão recursal, comunicando ao juiz sua decisão;

${ }^{30}$ Art. 258. Sempre que a lei não fixar prazo especial, o recurso deverá ser interposto em três dias da publicação do ato, resolução ou despacho.

Resenha Eleitoral (Florianópolis), v. 22, n. 1-2, p. 51-76, 2018 
são preclusivos com exceção dos recursos que discutam matéria constitucional, que pode ser alegada em próxima oportunidade ${ }^{31}$.

Essas normas, pois, saltam aos olhos de quem tem o primeiro contato com a matéria eleitoral. A imposição de prazo de três dias corridos para a interposição dos recursos por muitas vezes surpreende o mais desavisado, agravando-se, ainda, em período eleitoral ${ }^{32}$. Outro ponto, como dito, é a presunção de que os recursos não serão admitidos com efeito suspensivo, admitindo a exceção do parágrafo $2^{\circ}$ do artigo 257, sendo necessária, por vezes, a propositura de uma ação cautelar autônoma (ainda possível na seara eleitoral) para alcançar o efeito almejado.

Além disso, com vistas à celeridade processual, a Lei no 9.504 autoriza a intimação do candidato, durante o período eleitoral, por meio de fac-símile, sendo que o início do prazo é contado a partir do seu recebimento ${ }^{33}$ :

Além disso, insistindo na necessidade de celeridade e reduzindo a burocracia formal, também no período eleitoral autoriza-se o advogado a depositar no cartório eleitoral procuração ampla e genérica, sem que seja delimitado seu objeto, para que não se faça necessário apresentar nova procuração para cada processo (ou seja, deposita-se a procuração outorgada

${ }^{31}$ Art. 259. São preclusivos os prazos para interposição de recurso, salvo quando neste se discutir matéria constitucional.

Parágrafo único. O recurso em que se discutir matéria constitucional não poderá ser interposto fora do prazo. Perdido o prazo numa fase própria, só em outra que se apresentar poderá ser interposto.

${ }^{32}$ Durante o período eleitoral, inclusive, os prazos podem iniciar e terminar em finais de semana e em feriados, os quais correr em cartório, que funciona em regime de plantão (PEDREIRA; LOBATO, 2016):

Art. 16. Os prazos a que se referem o art. $3^{\circ}$ e seguintes desta lei complementar são peremptórios e contínuos e correm em secretaria ou Cartório e, a partir da data do encerramento do prazo para registro de candidatos, não se suspendem aos sábados, domingos e feriados.

No âmbito do Tribunal Regional Eleitoral de Santa Catarina, por exemplo, o plantão eleitoral perdura em dias úteis das 12 às 19h, e, em dias não úteis, das 14 às $19 \mathrm{~h}$ (Resolução TRESC no $7.942 / 2016)$.

33 Art. 96-A. Durante o período eleitoral, as intimações via fac-símile encaminhadas pela Justiça Eleitoral ao candidato deverão ser exclusivamente realizadas na linha telefônica por ele previamente cadastrada, por ocasião do preenchimento do requerimento de registro de candidatura.

Parágrafo único. O prazo de cumprimento da determinação prevista no caput é de quarenta e oito horas, a contar do recebimento do fac-símile. 
por certo candidato, que valerá para o pedido de registro, resposta à impugnação de candidatura, eventual impugnação a outro candidato, valendo o mesmo para o partido político) indicando número de fax e telefone para recebimento das citações, intimações e notificações (COELHO, 2011).

Pode-se ainda apontar como peculiaridade do Processo Eleitoral a intimação de advogados por meio de mural eletrônico. Ou seja, no período eleitoral, as intimações não são publicadas no diário oficial, mas sim em ambiente próprio alocado no site do tribunal respectivo, cabendo ao advogado fazer a consulta diária para tomar ciência das intimações ${ }^{34}$. Esse sistema é autorizado pelo parágrafo $5^{\circ}$ do artigo $94^{35}$ da Lei $\mathrm{n}^{\circ}$ 9.504, regulado no âmbito do Tribunal Regional Eleitoral de Santa Catarina pela Resolução n⿳o $7.948 / 2016^{36}$.

Percebe-se, pois, que o Direito Eleitoral possui peculiaridades que lhe são próprias, de modo que é preciso analisar detidamente princípios e

${ }^{34}$ Aos mais curiosos, é possível visualizar o mural eletrônico do Tribunal Regional Eleitoral de Santa Catarina no site dessa corte através do link: < http://www.tre-sc.jus.br/mural-eletronico/appview/muraleletronico/consultaMuralEletronicoForm.faces $>$. Acesso em: 13.11.2018.

35 Art. 94. Os feitos eleitorais, no período entre o registro das candidaturas até cinco dias após a realização do segundo turno das eleições, terão prioridade para a participação do Ministério Público e dos Juízes de todas as Justiças e instâncias, ressalvados os processos de habeas corpus e mandado de segurança.

$[\ldots]$

$\int 5^{\circ}$ Nos Tribunais Eleitorais, os advogados dos candidatos ou dos partidos e coligações serão intimados para os feitos que não versem sobre a cassação do registro ou do diploma de que trata esta Lei por meio da publicação de edital eletrônico publicado na página do respectivo Tribunal na internet, iniciando-se a contagem do prazo no dia seguinte ao da divulgação.

${ }^{36}$ Art. $2^{\circ}$ Durante o período referido no art. 1ํㅡㄹ as intimações de atos judiciais com previsão de realização por edital/mural eletrônico ou por publicação em Cartório/Secretaria serão veiculadas no Mural Eletrônico existente no sítio do Tribunal na internet, inclusive aos sábados, domingos e feriados (Resolução TSE n⿳o 23.455/2015, art. 38; Resolução TSE n⿳o

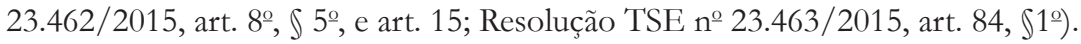

Parágrafo único. Entende-se por atos judiciais os despachos, sentenças e decisões monocráticas, inclusive as interlocutórias e as liminares, proferidas pelos Juízes Eleitorais, Juízes do Pleno, Juiz Corregedor e Juiz Presidente.

Art. 3- As intimações de atos judiciais publicadas no Mural Eletrônico serão realizadas diariamente, a partir das 21 horas, contando-se o prazo na forma do art.13, e ficarão disponíveis aos interessados, podendo ser visualizadas pela data da publicação e pesquisadas por unidade judiciária ou nome do procurador das partes. 
normas alheias ao microssistema antes de serem aplicadas, como é o caso do negócio jurídico processual.

\section{Incompatibilidade entre o negócio jurídico processual e o sistema eleitoral}

O microssistema do Direito Eleitoral é bastante amplo, relacionando-se com diversas outras esferas e trazendo para seu bojo muitas das normas que originariamente são de campos diversos. Assim, pode-se dizer que ele tangencia, em maior ou menor escala, o direito constitucional, a ciência política, a teoria geral do Estado, a teoria geral do direito, o direito civil, o direito administrativo, o direito penal e, ainda se pode afirmar que em grande escala com os direitos processuais penais e civis, sendo aqui estudada uma pequena parte dessa relação.

Contudo, a despeito dessa similitude e ainda de se ter vislumbrado que tanto o negócio jurídico processual quanto o direito eleitoral material derivam do Estado Democrático de Direito, não se pode concluir que são totalmente compatíveis.

Conforme visto, o processo eleitoral apresenta características frágeis que envolvem as muitas minirreformas implementadas, o Código Eleitoral editado durante a ditadura militar, a incerteza gerada pela constante edição de Resoluções pelo Tribunal Superior Eleitoral. Assim, acredita-se ser temerário possibilitar que o Processo Eleitoral, já repleto de peculiaridades e de incertezas, seja alterado livre e discricionariamente pelas partes.

Pelo apontado anteriormente, nota-se que o Processo Eleitoral já sofre anualmente inúmeras interferências e modificações por meio, principalmente, das Resoluções do TSE ${ }^{37}$, pondo em xeque a estabilidade processual e a segurança jurídica. Nesse ponto, repete-se, ampliar a instabilidade permitindo que as partes disponham livremente sobre o procedimento judicial imporia verdadeiro caos, levando-se em conta, também, a celeridade necessária inerente a essas ações.

\footnotetext{
${ }^{37}$ Marcelo Abelhas Rodrigues (2010, n.p.) defende que: "Assim, embora o papel do TSE esteja limitado a expedir resoluções e instruções que apenas deem fiel cumprimento à lei, a grande verdade é que tal órgão tem se imiscuído no papel de legislar, e, tem feito isso sob a justificativa (verdadeira) de que na ausência de norma federal - muitas vezes proposital - não poderia deixar o direito material eleitoral à mercê da vontade - ou falta de - do congresso nacional."
} 
A necessidade de julgamento iminente e os curtos prazos característicos da Justiça Eleitoral decorrem do exíguo período eleitoral (reduzido ainda mais a partir das eleições de 2016), de modo que admitir o negócio processual, da forma como preconizado pelo Código de Processo Civil ${ }^{38}$, significaria retirar a essência do Processo Eleitoral.

É bem verdade que os negócios processuais podem, de acordo com o seu teor, produzir o salutar substrato da celeridade processual. Contudo, em se tratando de autorregramento das partes, essa circunstância reflete uma faculdade delas, as quais, assim como podem convencionar prazos menores, podem fazer o seu contrário, dilatando-os de modo a prejudicar a velocidade inerente ao processo eleitoral. Por outro lado, permitir que as partes estivessem aptas a reduzir ainda mais os já exíguos prazos eleitorais também traria prejuízos ao seu adequado funcionamento, na medida em que importaria em esmorecimento dos princípios do contraditório e da ampla defesa.

Todo o sistema processual eleitoral foi desenvolvido com vistas a garantir celeridade e eficiência às decisões. Um exemplo disso é a ordem emanada do artigo 94 e seu $\int 2^{\circ}$ da Lei n⿳9 9.504/1997, segundo o qual o descumprimento à prioridade dos feitos eleitorais, compreendidos entre o registro das candidaturas até cinco dias após a realização do segundo turno das eleições, acarretará a imputação de crime de responsabilidade ao agente público, bem como será objeto de anotação funcional para efeito de promoção na carreira.

No mesmo sentido, o ministro do TSE, integrante da corte pela classe dos juristas entre o ano de 1983 e 1990, Roberto Rosas (1999), confirma a singularidade atinente ao Processo Eleitoral por conseguir implementar a tão sonhada rapidez no judiciário, uma vez que se revela célere. Segundo o autor, diante do curto período eleitoral ${ }^{39}$ é fundamental que assim seja.

${ }^{38}$ Lembra-se de que, de acordo com o artigo 190 do diploma processual, o juiz não tem a liberdade de vetar um negócio jurídico processual praticado por partes capazes e isonômicas, que não esteja maculado por alguma nulidade, nem tenha sido incluído de forma abusiva em contrato de adesão.

${ }^{39}$ Em seu artigo, Roberto Rosas faz referência ao período eleitoral que começava em abril e terminava em outubro, com o resultado das eleições. Contudo, em 2015, a Lei nº 13.165 alterou o disposto no artigo 11 da Lei no 9.504/1997, postergando o registro das candidaturas para 15 de agosto, encolhendo ainda mais o prazo de campanha propriamente dito.

Resenha Eleitoral (Florianópolis), v. 22, n. 1-2, p. 51-76, 2018 
Ademais, a incompatibilidade processual civil, ao analisar regras básicas do processo eleitoral, confronta diretamente com a ideia de aplicação irrestrita dos institutos previstos naquele diploma. Por exemplo, de definição e contagem de prazo. Como dito, o processo eleitoral tem como prazo referência de interposição recursal três dias contados de forma corrida (podendo iniciar e finalizar em finais de semana e em feriados durante o período eleitoral). Isso vai de encontro à regra processual civil que define a contagem do prazo exclusivamente em dias úteis e prevê prazo único para interposição de recurso e apresentação de resposta, excetuando os embargos de declaração, de 15 dias.

Para fins de esclarecimento, admitindo-se que fosse possível a aplicação do artigo 190 do Código de Processo Civil ao Processo Eleitoral, imagina-se que as partes acordassem modificações no procedimento previsto no âmbito eleitoral. Dessa forma, digamos que elas hipoteticamente definissem o prazo de 15 dias úteis para apresentação de contestação, período igual para réplica, audiência sem limite de testemunhas e indicadas a qualquer momento ${ }^{40}$, outros 20 dias para interposição de recurso, ou, ainda, que a instrução dos feitos relativos a eleições municipais seria feita pelos tribunais regionais. O procedimento que elas instaurariam dilataria em muito o preconizado pela legislação. Além disso, geraria grandes transtornos - tanto para a população, quanto para a justiça eleitoral - visto que, por exemplo, poderia permitir a eleição de um candidato inelegível.

Ou seja, se tomarmos como base: (i) o caso acima presumido; (ii) o artigo 11 da Lei no 9.504/1997, que estipula que os partidos e as coligações deverão, até as dezenove horas do dia 15 de agosto do ano em que se realizarem as eleições, registrar, perante a Justiça Eleitoral, os seus candidatos; e (iii) a Emenda Constitucional no 16/1997, que fixou que o $1^{\circ}$ turno das eleições ocorreria no primeiro domingo de outubro, e o $2^{\circ}$ turno, caso necessário, no último domingo de outubro, a situação anteriormente apresentada mostra-se de todo inviável.

\footnotetext{
${ }^{40}$ Nas ações de investigação judicial eleitoral (AIJE) previstas no artigo 22 da Lei Complementar n⿳0 64/1990, por exemplo, há muito a doutrina eleitoralista e a jurisprudência dessa justiça especializada já fixaram que o rol de testemunhas que se pretende serem ouvidas no bojo das Representações Eleitorais deve ser indicado na petição inicial pelo autor e na contestação, de modo que a sua ausência impõe a preclusão da produção da prova testemunhal (vide Agravo Regimental no RCED no 671). Tanto é que o TSE editou a Res TSE $n^{\circ}$ 23.462/2015, aplicada às eleições municipais de 2016, que expressamente consigna, no artigo $27, \int 1^{\circ}$ que: $\int 1^{\circ}$ As testemunhas deverão ser arroladas pelo representante, na inicial, e, pelo representado, na defesa, com o limite de seis para cada parte, sob pena de preclusão.
} 
Alargando ainda mais o exemplo, considerando que o negócio jurídico processual acima relatado fosse aplicado a uma Ação de Impugnação de Candidatura na eleição presidencial de 2018, teríamos 66 dias entre o registro da candidatura do aspirante a presidente e a data do segundo turno. Nota-se que o curto período e as normas definidas pelas partes são em todo incompatíveis, de modo que a sua aceitação permitiria que o candidato impossibilitado fosse eleito presidente da república. Desnecessário, pois, descrever o cenário caótico que essa situação geraria.

Destaca-se que, independentemente de fundamentação teórica - apesar de pertinente -, é materialmente inviável permitir que as partes possam alterar o procedimento tão específico e singular como o eleitoral.

No campo doutrinário, por sua vez, colhe-se ensinamento conclusivo de José Jairo Gomes (2016, p. 67), segundo o qual: "Sendo o Direito Eleitoral ligado ao Direito Público, suas normas são de natureza cogente (ius cogens) ou imperativas. Não podem, pois, ser alteradas pela vontade dos particulares ou das pessoas e entidades envolvidas no processo eleitoral."

Não bastasse, e principalmente, é de se destacar que não se trata exclusivamente de uma questão de incompatibilidades formais, temporais, processuais ou procedimentais, mas, principalmente, do fato de o Direito Eleitoral derivar diretamente da Constituição, e representar um dos principais meios para a efetivação da democracia.

A sociedade clama por liberdade, por representatividade, por segurança - e com muita propriedade, dado o histórico do nosso país -, contudo, não se pode, em nome desses desejos, ultrapassar o bem maior: a garantia de efetividade e manutenção da democracia.

Admitir a total liberdade das partes de alterar o procedimento eleitoral significa atribuir-lhes poder dotado da aptidão de, como demonstrado no exemplo, desvirtuar por completo o objetivo do Direito Eleitoral. É antidemocrático pensar em autorizar a eleição e manter no poder por quatro anos alguém que não foi honesto com a população e ganhou o pleito nas urnas em decorrência de omissão de fato pré-constituído sabidamente causador de inelegibilidade.

Evidente que há situações em que a vontade popular merece prevalecer sobre o ativismo judicial, contudo, em hipóteses extremas de causas constitucionais de inelegibilidade, ou de falhas tamanhas que mancham o direito passivo ao sufrágio, não se pode admitir que as partes tenham um poder maior que o da república e definir quem representará o povo pela legislatura seguinte. 
Nesse sentido, é de se refletir que, mesmo quando se fala em Processo Civil, de um modo geral, tem-se uma noção de sua natureza pública. Essa natureza, contudo, em se tratando de Processo Eleitoral, fica deveras reforçada em razão das consequências que traz para a coletividade como um todo.

Os interesses discutidos na seara eleitoral ultrapassam a esfera de interesses meramente pessoais de autor e réu (como comumente ocorre nos litígios civis), na medida em que a sociedade como um todo, ao compactuar com o contrato social, passa a ser responsável pela preservação dos direitos e das garantias constitucionais. Ou seja, a preocupação deve ser com o bem maior, independentemente, nesse caso, da maior conveniência procedimental das partes.

Logo, quando um procedimento eleitoral é alterado, tornando-se mais moroso ou recebendo alguma restrição probatória convencionada que possa vir a acarretar dúvidas quanto à justiça da decisão final, não são apenas os litigantes que saem prejudicados, mas todo o Estado Democrático Brasileiro.

Lembra-se, por fim, de que o TSE editou a Resolução $\mathrm{n}^{\mathrm{o}}$ 23.478/2016, a qual definiu como se daria a aplicação do Novo Código de Processo Civil na justiça eleitoral. A resolução, então, estabelece em seu artigo 11 que: "Na Justiça Eleitoral não é admitida a autocomposição, não sendo aplicáveis as regras dos arts. 190 e 191 do Novo Código de Processo Civil."

Certo que a resolução não externa os motivos considerados para a edição de cada um dos artigos, mas de um modo ou de outro, pode-se perceber que a preocupação é difundida, o que resultou na impossibilidade de aplicação do negócio jurídico processual no direito eleitoral.

Dessa forma, ao confrontar a manutenção e a proteção de direitos fundamentais com a absorção de instituto alienígena não pensado para especificidades como as que circundam o Direito Eleitoral, não há dúvida de que a Constituição deve prevalecer e, portanto, negar aplicação do instituto do negócio jurídico processual a esse ramo do direito, reconhecendo-se a incompatibilidade entre o instituto do negócio jurídico processual previsto no Novo Código de Processo Civil e o Direito Eleitoral.

\section{Considerações finais}

A enfática valorização que vem sendo concedida ao autorregramento da vontade nos litígios instaurados perante o Poder Judiciário consiste em uma inegável tendência do Direito Processual Civil, rompendo Resenha Eleitoral (Florianópolis), v. 22, n. 1-2, p. 51-76, 2018 
com paradigmas até então vigentes e instaurando novos. Contudo, como bem se pode notar, tal lógica não pode ser aplicada ao Processo Eleitoral.

Não se desconsidera a evolução que o Código de Processo Civil de 2015 trouxe ao sistema jurídico brasileiro, contudo, deve-se aceitar os seus limites, não se admitindo recebê-lo com o ordenamento universal aplicável a qualquer procedimento não penal.

O Direito Eleitoral, com seu amplo fundamento constitucional, merece ser visto pelo que ele é: instrumento de concretização da democracia. Assim, não se pode pôr em risco os direitos e as garantias constitucionais ao bem da conveniência e da liberalidade das partes.

Portanto, como visto, o negócio jurídico processual é um instituto que, apesar de não ser novo, inovou o Processo Civil brasileiro e apresentou inúmeras vantagens na seara civil, inclusive, ao concretizar direitos dos cidadãos típicos do Estado Democrático contemporâneo.

Ele facilitou o acesso à justiça e a efetivação da ampla defesa, visto que molda o procedimento à necessidade das partes, evitando gastos excessivos, tanto temporal quanto financeiros (com peritos, dilação probatória, recursos indesejados).

O Processo Eleitoral, por sua vez, possui infinitas particularidades que o afastam do Processo Civil, de modo que, apesar de haver previsão expressa no novo diploma de que a sua aplicação será supletiva e subsidiária, essa leitura deve ser feita de modo consciente, detalhada e profunda, a fim de identificar e de respeitar os limites que devem ser respeitados.

Por fim, uma forma de evitar novos dilemas e impasses seria a edição do Código de Processo Eleitoral, o qual recepcionaria em seu texto os instrumentos disponíveis no Código de Processo Civil de forma que melhor se adaptasse, e aclararia as incompatibilidades de modo a prestigiar o sistema processual e, principalmente, a Constituição da República.

\section{Referências}

BRAGA, Paula Sarno. Primeiras reflexões sobre uma teoria do fato jurídico processual: plano de existência. Revista de Processo, São Paulo, RT, v. 148, jun./2007.

BUCHMANN, Adriana. Limites objetivos ao negócio processual atípico. 2017. Dissertação (Mestrado em Direito) - Universidade Federal de Santa Catarina, Florianópolis, 2017. 
COELHO, Alexandre Damasio. Citação e intimação no processo cível eleitoral. Blog de direito eleitoral e de direito público. jun. 2011. Disponível em: <http://alexandredamasiocoelho.blogspot.com.br/2011/06/citacao-e-intimacao-no-processo-civel.html>. Acesso em: 6 maio 2017.

GAJARDONI, Fernando da Fonseca. Procedimentos, déficit procedimental e flexibilização procedimental no novo CPC. Revista de Informação Legislativa, Brasília, ano 48, n. 190, 2011.

GOMES, José Jairo. Direito eleitoral. 12. ed. rev. atual. amp. São Paulo: Atlas, 2016. GRECO, Leonardo. Os atos de disposição processual - primeiras reflexões. Revista Eletrônica de Direito Processual, 1. ed., out./dez. 2007.

GRINOVER, Ada Pellegrini; DINAMARCO, Cândido Rangel; CINTRA, Antonio Carlos de Araújo. Teoria geral do processo. São Paulo: Malheiros, 2004.

LENZA, Pedro (Coord.) Direito eleitoral esquematizado. São Paulo: Saraiva, 2011.

MOREIRA, José Carlos Barbosa. Convenções das partes sobre matéria processual. Revista Brasileira de Direito Processual. Rio de Janeiro, n. 40, p. 81-96, out./dez., 1983.

PEDREIRA, Rodrigo; LOBATO, Rafael. A contagem de prazo no novo CPC e o processo eleitoral. Revista Consultor Jurídico. 1 abr. 2016. Disponível em: <http://www.conjur.com.br/2016-abr-01/contagem-prazo-cpc-processo-eleitoral>. Acesso em: 7 maio 2017.

RODRIGUES, Marcelo Abelha. A subsidiariedade do CPC no processo eleitoral. 2010. Disponível em: <http://www.marceloabelha.com.br/ publi/A $\% 20$ subsidiariedade $\% 20 \mathrm{do} \% 20 \mathrm{CPC} \% 20$ no $\% 20$ processo $\% 20$ eleitoral_1_.docx>. Acesso em: 6 maio 2017.

ROSAS, Roberto. Justiça eleitoral: modelo e importância. Revista de Direito Constitucional e Internacional, v. 27, p. 45-51, abr./jun. 1999.

SANTOS, Marina França. Intervenção de terceiro negociada: possibilidade aberta pelo novo Código de Processo Civil. Revista de Processo, São Paulo, v. 40, n. 241, p. 95-109, mar. 2015.

SUPERIOR TRIBUNAL DE JUSTIÇA. Enunciado administrativo no $\mathbf{1}$, de 2 de março de 2016. Disponível em: <http:/ /www.stj.jus.br/sites/STJ/ default/pt_BR/Institucional/Enunciados-administrativos>. Acesso em: 25 abr. 2017. 
TRIBUNAL REGIONAL ELEITORAL DE SANTA CATARINA. Resolução no 7.942, de 9 de maio de 2016. Dispõe sobre os plantões judiciais de que trata a Lei Complementar no 64, de 18 de maio de 1990. Sala de Sessões do Tribunal Regional Eleitoral de Santa Catarina, Poder Judiciário, Florianópolis, SC, 9 maio 2016. Disponível em: <http:/ /www.tre-sc.jus.br/site/legislacao/resolucoes/tresc/2016/resolucao-tresc-n-79422016/index.html>. Acesso em: 7 maio 2017.

. Resolução n⿳⺈ 7.948, de 4 de julho de 2016. Dispõe sobre a utilização do Mural Eletrônico da Justiça Eleitoral de Santa Catarina durante o período estabelecido em Calendário Eleitoral. Sala de Sessões do Tribunal Regional Eleitoral de Santa Catarina, Poder Judiciário, Florianópolis, SC, 4 jul. 2016. Disponível em: <http://www.tre-sc.jus.br/site/legislacao/resolucoes/ tresc/2016/resolucao-tresc-n-79482016/index.html>. Acesso em: 7 maio 2017.

\section{TRIBUNAL SUPERIOR ELEITORAL. Em São Paulo, ministro Gilmar} Mendes fala sobre reforma eleitoral. 6 mar. 2017. Disponível em: <http:/ / www.tse.jus.br/imprensa/noticias-tse/2017/Marco/em-sao-paulo-ministro-gilmar-mendes-fala-sobre-reforma-eleitoral>. Acesso em: 6 maio 2017.

VENAGLIA, Guilherme. A conta e o faz de conta das eleições. Revista Veja (on-line), 6 maio 2017. Disponível em: < http://veja.abril.com.br/politi$\mathrm{ca} / \mathrm{a}$-conta-e-o-faz-de-conta-das-eleicoes/>. Acesso em: 8 maio 2017.

Luiza Cesar Portella - Pós-Graduada em Direito Processual Civil pela Faculdade Cesusc. Graduada em Direito pela Universidade Federal de Santa Catarina (UFSC). Graduada em Administração Empresarial pela Universidade do Estado de Santa Catarina (UDESC/ ESAG). É advogada militante nas áreas de direito eleitoral e direito administrativo (Sócia do Escritório Menezes Niebhur Advogados Associados). É membro da Comissão de Direito Eleitoral da $\mathrm{OAB} / \mathrm{SC}$.

Luiz Magno Pinto Bastos Junior - Pós-Doutor pelo Centro de Direitos Humanos e Pluralismo Jurídico da Universidade McGill (Montreal, Canadá). Doutor e Mestre em Direito pela Universidade Federal de Santa Catarina (UFSC). Graduado em Direito pela Universidade Federal do Pará (UFPA). Professor da Universidade do Vale do Itajaí (UNIVALI), nas disciplinas de Direito Constitucional, Direito Eleitoral e Direitos Humanos no curso de Graduação em Direito. É advogado militante nas áreas de direito eleitoral e direito administrativo (Sócio do Escritório Menezes Niebhur Advogados Associados). É membro fundador da Academia Brasileira de Direito Eleitoral e Político (ABRADEP) e Academia Catarinense de Direito Eleitoral (ACADE). Coordenador do Observatório do Sistema Interamericano de Direitos Humanos (UNIVALI). 